\title{
Examination of Issues of Attitude to the Place and Role of Women of Uzbekistan in Society in the Xx Century
}

\author{
Djuraeva Nilufar Dalibayevna
}

\begin{abstract}
The article analyzes the place and role of women in society in the twentieth century and their social status. At the beginning of the twentieth century, the views of Turkestan jadids on this issue, the study of women's problems in the Soviet period and the importance of state policy towards women in the years of independence were covered from a scientific point of view.

Keywords: women, society, social status, Turkestan, the Jadid movement, the education of women, the Soviet era, the years of independence, state policy.
\end{abstract}

\section{INTRODUCTION}

At all stages of society's development, the Uzbek people have a historically distinct mentality in promoting women's social activism. Traditionally, the devotion of women to their motherland and family has been raised to the level of spirituality. Accordingly, the role of women in the national mentality system plays an important role.

As President Mirziyoev put it: "Our people have always been respecting the Holy Mother and women. Respect for women is, above all, an expression of respect for the family, for the future of society.

From this point of view, the words of wisdom, "The cultural level of any society on earth, are determined by its attitude towards women".

In the current globalization, the protection of the rights and freedoms and legitimate interests of women is becoming more and more important. In particular, increasing the socio-economic and political-legal activity of women is becoming a requirement of the time".

The importance of women's social activity in shaping the spirituality of society and their involvement in the cultural and educational field, which has a historical basis, is reflected in the sources. This issue is also reflected in the works of medieval eastern scholars. Specifically, as Abu Nasr Farabi wrote, a just leader will keep society from ignorance and spirituality and lead it to progress and prosperity. Therefore, a leader who possesses these qualities also has a particular responsibility to enhance the prestige of women in society.

Historical findings show that early Turkestan educators responded to the issue of women's role in society in the early twentieth century by encouraging women to gain a foothold in society, struggling to create conditions for their contribution to society. can be seen in the local press at the beginning of the century.

Revised Version Manuscript Received on 16 September, 2019.

* Correspondence Author

Turaev Mukhtor Murodovich, PhD (Biology) Bukhara State University, Bukhara, Uzbekistan

Kholliyev Askar Ergashovich, DSc (Biology) Bukhara State University, Bukhara, Uzbekistan
Recognizing that with the encouragement and education of women in the late nineteenth and early twentieth centuries, the Jadids were doing great advocacy to deepen and educate women on the reform of the nation. Jadids have come up with the idea of reforming society to address the problem of women in their program activities, recognizing the rights of Muslim women and the traditional patriarchal attitudes that exist in society.

Promoting the importance of women's involvement in social life, equality of women with men in society, prohibition of juvenile marriage was first and foremost reflected in the action plan of our educators. However, these ideas are not formally stated in any of their special documents. Nevertheless, some documents and memoirs show that Jadids were the first to raise the issue of Muslim women participating in the elections to the authorities.

In particular, the Najot newspaper of April 28, 1917 noted that one of the most acute issues of the conflict between the local progressives and the antiquities, which was greatly influenced by the February Revolution of 1917, was the participation of Turkish women. . .

Ancientists have suggested that women's participation in public political activity is contrary to the principles of Shari'a and doctrine. They resorted to a series of guidelines that justify and illuminate the inequalities of women in the Koran, the Muslim holy book, and try to prove that they are incapable of participating in secondary social and political activities. According to them, the main purpose of women is to serve their husbands obediently, because "husbands are superior to their wives, because God has given the former superiority over the latter, and therefore they spend their property." No.5-6).

In this regard, the Hurriyet newspaper later wrote: "It is interesting to note that these noble men did not pay attention to the fact that women had freely visited the wedding, the guest, the cemetery. Now, when it is time to take over our religious and national rights, they oppose women's participation in the elections. "(Freedom, July 18, 1917).

The Council of Ulkamuschur Council condemned the actions of the ancients regarding the participation of women in the election and warned that if Turkestan Muslims remain so, they will lose half their suffrage. For this reason, we cannot have representatives not only in the Duma but also in the Constituent Assembly (Council), July 25, 1917.

Theoretical background Progressives explained to them that during the election, women would be under special scrutiny and that Muslim morality would be respected. Women come to the polling booths with

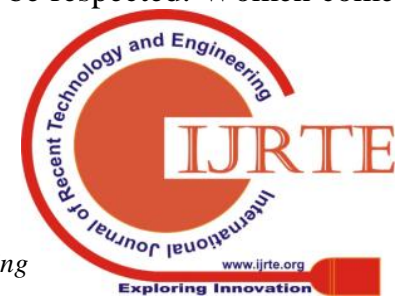




\section{Examination of Issues of Attitude to the Place and Role of Women of Uzbekistan in Society in the Xx Century}

hijabs and throw ballots in specially designated rooms. Ultimately, the Congress of the Muslims made the following decision:

1. From today (April 20, 1917) the preparation for the Constituent Assembly begins.

2. Equal rights for Muslim women in electing delegates to the Constituent Assembly.

3. The participation of women in elections should be within the framework of Shariah.

The jihadist movement has embraced new ideological movements in the development of society to restore the socio-political rights and freedoms of women, to ensure their active participation in the socio-political processes, to educate them and to overcome old medieval relations with them. to promote Western achievements. Because Jadids are well aware that the arbitrariness, oppression, injustice, ignorance, and violence that prevail in an uneducated society are, first and foremost, manifested in women's lives more quickly and fully. That is why they are exploring the possibility of educating women, enhancing their social activism, exploiting their talents and abilities, creating opportunities for religious and secular science, and equating Uzbek women with equal rights as men in Europe. called to live.

Jadids "cannot accept women as full-fledged members of society, properly address family issues, nurture a younger generation on the right path, without reforming society and directing its development. Ultimately, the fate of the nation depends on the status of women and their families." and struggled to put the following ideas into practice:

- Increasing women's status in the family by establishing their place in the family, and ensuring equal participation in religious and secular affairs;

- educate women on the basis of the nation's support for the nation, the responsibility of the younger generation in social, moral and labor education;

- change the negative attitude towards women as the cultural and moral level of any society is determined by their attitude towards women.

At the heart of these ideas of Jadids is the unique role of women in the history of mankind and the fact that family is the cornerstone of society. Issues of women, families, and society, as put forward by the ideology of Jadid, are aimed at addressing universal issues, which are still relevant today.

Unlike the Jadids, the Soviets used their own colonialist policies to engage women in social and political life. Including:

- the Soviets sought to reach out to indigenous women in the socio-political sphere, to join their party, and achieve their supporters in building a "new socialist society";

- tried to disseminate the patriotism and patriotism inherent in the nature of Uzbek women into the so-called Union;

- the Soviets pursued a policy aimed at preventing the exploitation of indigenous women and their political and legal awareness;

- this, in turn, prevented the indigenous peoples from being born with the innate need for self-awareness and the struggle for independence.

The program goals of the jihadists to modernize society, increase women's social activism, and disseminate secular knowledge were in part consistent with the slogans of the Communist Party. However, based on the aggressive policy of the Soviet government, the motives for women were concealed. As the Jadids promoted the idea of national independence and fought for independence, the totalitarian Soviet power was the first victim of repression. As a result, the Uzbek women lost their support to the social group, which they favored in their struggle for their rights.

In the early years of the Soviet government, the role and place of women of indigenous peoples in society, in cultural and educational processes, was largely researched by women activists. However, in their articles and brochures, the involvement of indigenous women in the socio-political, economic and cultural life was illuminated in one-sided, classical ways, and served to promote Soviet policy. In these literature, attempts have been made to demonstrate the role of pseudo-communist ideology as a "revolutionary transformer" in the political system, in public life, and are only positively assessed. Later, local experts were also involved in the research. However, in these works, the policies of the totalitarian regime against women were positively assessed and discriminated against for the sake of the Soviet interests, as nationalist, religious, and traditional values inherent in Oriental women have been shaped for centuries. . The very idea of the struggle against national, religious and traditional values was the basis of the literature of the Soviet period.

Articles and pamphlets on women's issues and their "resolution" were mainly created by women of local ethnicity, who were leaders in Soviet and party organizations. In their works, the essence of women's "freedom" was analyzed from the perspective of the Communist Party's goals and interests. Since the 50s, the issue of women has been explored as a research activity. However, these studies were mostly factual in nature and included narratives of historical events related to the throwing of the veil. At the same time, the authors did not comment on a number of important issues, including the opposition of the local population against the "freedom" of women and the difficulty of integrating the new understanding of women's equality into a traditional way of life where patriarchal privilege is strong. Most studies have stated that the movement for women's "freedom" was smooth, organized, planned, and without complications.

\section{LITERATURE REVIEW}

In the $1960 \mathrm{~s}$, the study of the problem of women became more profound, and scientific articles, Ph.D., and monographs were created. Although they were the first general works on the basis of extensive archival materials and source literature, they were written in the form of a single political ideology and the essence of many important issues was distorted.

In the 1970s, the study of the history of "problem solving" of women's issues in the Central Asian republics intensified. In particular, the social status of women in Uzbekistan and issues of women's movement are reflected in the studies of HS Shukurova, RH Aminova, SO Begmatova, M. Bahritdinova, M. Ziyamuhamedova and other historians. However, it should be noted that the literature of this period also has some drawbacks. In particular, the current regime of liberating Central Asian women has not been silent on the effects of discrimination, neglect on traditional values, the use of violence, the negative effects of industrialization and collectivization policies on women's lives. 
Issues related to the particular social problems of Central Asian women and their plight were only raised in the late 1980s. In the mid-1980s, there was a social need for the rise of national self-consciousness and the revival of historical truth as a result of the "politics of reconstruction", "new thinking", the growing process of democracy and transparency, the relaxation of the pressure of the dominant ideology. In the early years of the "reconstruction", as before, the role of women in social production was assessed positively. However, for the first time in the pamphlets by R.H. Aminova, RJajapova, R.A Ubaydullaeva, V.Ghebotaryova, published in the 60th anniversary of the attack and the history of the women's movement, women were involved in social production. problems, improvement of their working conditions, increasing the attention to the lifestyle. They work harder and harder in the heavy industry, which is incompatible with the specifics of their organisms, the problem of efficient use of women's labor is not limited to production issues, the difficulty of carrying out qualified work with family responsibilities, comments on opportunities for women with many children to work part-time. The service of the literature of the "Reconstruction" years was that it justified the need for a new methodological approach to the assessment of women's movement. However, this issue has not been fully resolved. This was because of the continued dominance of the communist ideology and the survival of the totalitarian system.

A critical analysis of the literature published during the Soviet period enables us to reach the following conclusions:

- The researches created so far have accumulated and summarized the rich factual materials reflecting historical events, but all of these studies were written during the reign of ideological dogmas, with the strongest influence of the dominant ideology of that time;

- the issues studied are unilaterally politicized and highly politicized from the point of view of the official views under the pressure of communist ideology;

- The essence of the research is to substantiate the unofficial conclusion that the Soviet government had "solved" the issue of women, and to fight against national, religious, and traditional values. After the independence of the Republic of Uzbekistan, the collapse of the former Soviet Union, the revival of historical truth and national spirituality allowed the state of women in Uzbekistan to be viewed as an important social issue. In the first years of independence, historians R. Aminova and DA Alimova explored this issue from the point of view of the present. In particular, R. Aminova in her book "Actual Problems of Social Development in Uzbekistan in the Reconstruction" states that women's higher education is incompatible with their vocational training, and that their low-skilled or unskilled labor is higher than that of men. The share of women engaged in manual labor in agriculture, construction, and agriculture is much higher than in the country. The share of manual labor in the national industry was $35.3 \%$, and among women $-42.5 \%$. Still, the hard work of women is not over." The scientist points out two groups of these problems: the first is the low level of technical equipment in women's labor, and the second is that the training of women is insufficient. The historian says that the "Reconstruction" policy has made it clear to women about the social, economic, and domestic problems that have accumulated during the recession, but the old relationships that have remained in the family for 70 years have not allowed women to tell the truth, and have led them to despair, especially domestic rebellion. he regrets that it was the hardest way to express his self-esteem. In the scientific monograph of D. Alimova the problem of women is critically studied on the basis of the analysis of comprehensive documentary sources and archival materials. The role of women in the socio-political and cultural life of Central Asia has been historically highlighted. The scientist also discusses the issue of women - only the 'Attack' movement has been assessed on a new basis, but its history and the issue of 'women's cooperation', the impact of agricultural policy on women's situation, the emancipation of women in land and water reform in 1925-29. the role of public organizations in this area, the involvement of women in social production, the interrelation of cultural development with the formation of new types of women, the basis of the national ideology of independence. It was said a study of the actual. A number of scholarly articles for the first time have highlighted the traditional, societal views on the role of women in family and society and their historical roots. In the second half of the 1990s and 2000s, a new historical approach, with a new approach and methodology, focused on the study of women's position in almost every field of history and social sciences, such as economics, philosophy and law, and a number of candidates for women. doctoral dissertations are also defended. In this dissertation the colonial essence of Soviet authorities' attitude towards women in the period under study was scientifically and objectively explained. However, these studies have reflected some aspects of the problem.

Ya.Abdullaeva's book "Women of Karakalpakstan: Yesterday and Today. It is worth mentioning special monographs and articles of the late 19th and 20th centuries. In her monograph Ya.Abdullaeva is the first to clearly state that the policies of the Soviet authorities and the Communist Party have had the opposite nature, positive and negative, and created specific working methods, forms and mechanisms of their work. illustrated by examples. Created a classification of the work done by the Soviets and the Communist Party ${ }^{2}$.

N.D Juraeva's Thesis on "The Role of Women in the Socio-Economic and Cultural Life of Uzbekistan (20-30s of the 20th Century)" The scientific idea of the colonial nature of Soviet policy in relation to women in the early years of Soviet policy analyzed. In the 20th century, Soviet researchers' attitude toward indigenous women also attracted Western researchers. These include Western scholars of the 20 s of Central Asian women's emancipation issues: A. Benningsen, L.K Shantal, A. Alleg and American researchers Rudolf Broda, political commentator Luis Fisher, journalist Anna Louise Strong, political scientist Barbara Jankar, Vensan Learned by Montey, Frank Adolf, Walter Kolarts, Herbert Dipersstein, Elizabeth E. Bacon, Alexander Park, Norton Toj. Some of them positively rated the Soviet authorities' attitude towards women, while many researchers commented on Soviet ideas about the "solution to the problem of women" and highlighted Soviet policy on women in Russian colonialism. Politics, the oppression of the Russian people by the local people.

In particular, Rudolf Broda, Luis Fischer, and Anna Louise Strong positively assessed the Bolsheviks' policies toward women, while American political scientist Barbara 


\section{Examination of Issues of Attitude to the Place and Role of Women of Uzbekistan in Society in the Xx Century}

Jankar used women as a social work force, primarily because of the development of the economy. "The percentage of women working in any country in the world is very low, except socialist countries." This view is also supported by French orientalists A.Benningsen and L.K.Shantal, S.Wimbush and M.Broksap, and criticizes that the Soviet state ignored indigenous, religious and traditional factors of the indigenous people and pursued a policy of rejection of national interests. French scientist John Schomart de la Lois commentes on the negative effects of heavy industrial production on women's bodies and their implications. At the same time, it is argued that the Soviet policy of "liberating" indigenous women was a hasty, campaign-driven, narrow-minded approach.

Many pages of Western researchers' works have been published by the London-based Central Asian Research Center and published in the journal Sredneaziatskoe Obozrenie, led by Jeffrey Willer. In particular, Vensan Montey concludes in his book Free Woman that Soviet involvement in women's social production led to the disappearance of women's crafts. Boymirza Hayit calls the Soviet marriage and family legislation "a violation of family life". Indeed, the Soviet policy of liberating women was to intervene directly in the family affairs of the Uzbek people. Frank Ecker of the University of Michigan in the United States: Transition in Asia: Uzbekistan during the Soviet Period analyzes the lives of rural women in Uzbekistan, linking their release to the need for women's labor in cotton and other fields. Alexander Park, a senior fellow at Columbia University in the United States, has linked Soviet anti-religious policies to obstructing women's social activism. Writer, journalist and radio commentator Walter Kolarts in the book "Religion in the Soviet Union" condemns the persecution of religious believers and argues that progressive religious leaders are fighting against the non-Islamic traditions and old fashioned attitudes of Muslim women. Walter Kolarts also calls the history of the attack an "anti-paranoia campaign" and argues that "this campaign has not been useful to communism." This means that many women have been murdered and humiliated.

\section{Main part}

Herbert Dipersstein from the USA states in his books "Sovietization of Uzbekistan" and "Russian Thought and Politics" that "in the first years of Soviet rule, nothing was done to free Uzbek women."

Willer, an English scientist, analyzes Soviet policy of engaging women in cultural and educational processes, and says that there is still much to be done in higher education for women, and that American sociologists are underestimated. Paul Seks, Gail-Warshofska-Lapidus, S. Shuysky, M. Fishbach also support this view.

Scientist Marian Kamp of Indiana University, Marianne Camp, discusses the changing role of Turkic women, especially Uzbek women, in various government structures since the 19th century, and their role in society. "(The new woman in Uzbekistan: Islam, Modernity, and Unveiling under Communism). According to Olympia Camp, the Jadids of the Colonial period to engage women in science and to establish their place in society were the basis for Soviet-era women. In other words, the ideas and efforts to educate women and create conditions for them to contribute to the development of society began long before the formation of the Soviet system and the Communist Party.

One of the works of foreign scholars dedicated to the spirituality and enlightenment of Uzbek women is a book by German scientist Gabriel Keller, published in 2003, entitled "Women's Culture in Uzbekistan: European Women in the footsteps of ancient traditions in Central Asia." It reflects the tales of the scientist, who travels in cities and villages of Uzbekistan, and presents various aspects of women's culture, with photos in German, Uzbek, English and French. At the beginning of the article, the author writes that she liked a cradle wedding in Samarkand, bibimushulkushad and women's dances. She is one of the foreign scholars (Z.Baran, Z. Brzezinski and others), who recognize the liberal and democratic nature of Islam in Uzbekistan, concluding that "Islam in Central Asia is a sacred secular religion that combines features of other ancient religions." can also be found. German ethnographer Gabriele Keller visited Uzbekistan in 1997-2000 and organized an exhibition on Uzbek women culture as a result of her experiences and experiences in the country. The photos from the exhibition show his expeditions to Tashkent as a fairy-tale scientist. This is the result of research and development in Germany in 2001, entitled "The Tales of Samarkand. The Great Silk Road Research in Uzbekistan ". This publication was reissued in 2002. Due to her interest in fairy tales, Gabriele Keller acquainted with Uzbek families and Uzbek women. She learned about Uzbek women 's family status, national values and traditions, and the culture of family life. She gave detailed information about the commitment of Uzbek women to values and about their cultural and educational lifestyles today. G. Keller is the first woman to hear and document Uzbek folk tales. In the spring of 2000, a photo exhibition titled "Women's Culture in Uzbekistan - European Woman in the Footsteps of Ancient Traditions in Central Asia" was organized in cooperation with the Goethe Institute in Tashkent. The exhibition was first shown to the Uzbek people at the Exhibition Hall of the Academy of Arts of Uzbekistan in Tashkent, then at the State Historical Museum in Samarkand's Registan Square, the Bukhara State Library and the Tennis Palace in Termez, and at the same time through the Republican National Television and Radio Campaign.

A collection of exhibits and photographs from Gabriele Keller's ethnographic collection about Uzbekistan were on display in various European countries. And it gave rise to an idea of the customs and national values of the Uzbek people, which are not yet well known in European countries, resulting in a genuinely fair view of independent Uzbekistan and its great Uzbek people. And this is a worthy contribution to the strengthening of friendly relations between Uzbekistan and Germany. In conclusion, in the years of independence the role of women in society, their respect, protection of their interests, improvement of working and living conditions has become one of the priorities and goals of state policy, and the issue of women has been raised to the level of state policy and strategy.

At this new stage of development, Uzbekistan has undergone wide-ranging reforms in the socio-economic, cultural and educational spheres of society, and in the process, the quality of women and their participation in solving fundamental problems are growing. As Sh.Mirziyoev 
noted: "At present, women make up $45 \%$ of the total number of workers and employees in various fields and industries. In particular, more than 1,400 nurses are working in government and public organizations. Of these, 17 are senators, 16 are members of the Legislative Chamber of the Oliy Majlis, and 1 7575 are members of local councils of people's deputies.

In modern society, the process of self-identification of women is changing and their social status, culture and education are growing. This process has attracted the attention of many researchers, but shows that dealing with women's issues is not accidental. In particular, the recognition of the issue of women as a worldwide social phenomenon and the consistent efforts to overcome the problem of women, their broad participation in social life, enhance the role of women in society and create a wide range of activities for them. As a result, they have the opportunity to demonstrate their talents and abilities whilst maintaining their economic independence.

\section{CONCLUSION}

This process has led to changes in the policies and attitudes of almost all countries regarding women's policies. The world is fully aware that the future of the nation and society is fully embraced by the participation of women, and that society can have a perfect direction in its development only if it is actively involved in science, technology, production and management in all spheres of social life. That is why, in today's globalization and the clash of civilizations, the issues of further developing the role and place of women in modern society, which cannot be achieved without the participation of women, are important. Because, as the wise say, men are the nation today, women are the future.

\section{REFERENCE}

1. Agzamkhodzhaev S. The Turkestan Autonomous Region. - Tashkent: 2000, Spirituality. -page. 97-98. (165 pages in total)

2. Abdullaeva Ya.A. Women of Karakalpakstan: Yesterday and Today. The end of the 19th and 20th centuries. -T .: Creative world. 2004. -2424; The author of the same article. The Soviet policy of forced Soviet farming in Karakalpakstan and the repression of rural women // History of Uzbekistan. 2002. No. 2. p. 40-45; The same author. Some causes of the crisis of the dictatorial Soviet system and its impact on the state of women (on the example of Karakalpakstan) // Democratization and human rights. 2004. No. 1. p. 42-45; The same author. Reproductive law or repression of the totalitarian system // Life and law. 2004. No. 2. p. 58-59; The same author. Attack on belief // Thinking. 2004. No. 2. p. 90-92.

3. The Constitution of the Republic of Uzbekistan. - Tashkent: Uzbekistan, NMU, 2012.

4. Mirziyoyev Sh. Holiday greetings for women of Uzbekistan // March 8, 2019

5. Speech by the President of the Republic of Uzbekistan ShavkatMirziyoyev at the twentieth plenary meeting of the Senate of the OliyMajlis. 06/22/2019. // People's word, June 23, 2019 // uza.uz

6. Decree of the President of the Republic of Uzbekistan "On measures to radically improve activities in the field of supporting women and strengthening the institution of the family" // February 2, 2018

7. Sultanova E. A woman is in the state development strategy (as a global challenge). Ink.the science. DR. ... diss. Abstract. - Tashkent, 2006 .- 36 p.

8. Fitrat A. Family. - Tashkent: Spirituality, 1990. -p. 34

9. Mustafayeva N. Problems of the role of women in the family and society of the Turkmen national intelligentsia // The role of women and gender problems in the family, state and social construction in Uzbekistan (Conference proceedings, June 17, 1999). -T .: Science. 1999 .-- p. 42; I. True. Education Issues // Participation. 1919.p. 134.

10. Mustafayeva N. Problems of the role of women in the family and society of the Turkmen national intelligentsia // The role of women and gender problems in the family, state and social construction in Uzbekistan
(Conference materials, June 17, 1999). -T .: Science. 1999 .-- B. 41; A Avloni. TA.2 Volume 2 Folder. $-\mathrm{T}$.: Spirituality. 1998. - p.37. 